\title{
Inosine-5'-Monophosphate Dehydrogenase 1
}

National Cancer Institute

\section{Source}

National Cancer Institute. Inosine-5'-Monophosphate Dehydrogenase 1. NCI Thesaurus.

Code C38923.

Inosine-5'-monophosphate dehydrogenase 1 (514 aa, $~ 55 \mathrm{kDa}$ ) is encoded by the human IMPDH1 gene. This protein plays a role in guanine nucleotide biosynthesis. 